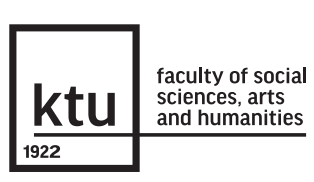

SAL 39/2021

Research Journal Studies about Languages pp. $41-55$

ISSN 1648-2824 (print)

ISSN 2029-7203 (online)

DOI 10.5755/j01.sal.1.39.29953
LINGUISTICS / KALBOTYRA

On Cooperation and Im/Politeness in French Interactions

Received 01/2021

Accepted 10/2021

Crossef http://dx.doi.org/10.5755/j01.sal.1.39.29953
HOW TO CITE: de Oliveira, R. (2021). On Cooperation and Im/Politeness in French Interactions. Studies about Languages / Kalbų studijos, 39, 41-55. http://doi. org/10.5755/j01.sal.1.39.29953

\title{
On Cooperation and Im/Politeness in French Interactions
}

\author{
Apie bendradarbiavimą ir (ne)mandagumą bendraujant prancūzų kalba
}

\author{
RUTH DE OLIVEIRA, University of Cape Town, South Africa
}

\begin{abstract}
In Culpeper's (2009) extensive study of how impoliteness-related terms are used, especially in relation to people's expectations in public-service contexts, the term "french" occurs twice, along with "doorman," "bouncer," "bartender," "waitress," "waiter," "yorker," "staff." Based on this, could one suppose that, in daily interactions in French, the principles of cooperation (Grice, 1975) and politeness come into conflict, leading to the characterization of speakers as impolite? If this is the case, why? How does it occur? Is this characterization specific to public-service contexts, or does it extend to other domains of social life? Aiming to provide answers to these questions, this study draws on the framework of conversation analysis using a socio-pragmatic approach (from Austin, 1962, to Kerbrat-Orecchioni, 2010, and Culpeper, 2021). Guided by socio-cultural and historical factors (Bourdieu, 1984; La Bruyère, 1688), it explores the concept of linguistic im/politeness (Culpeper, 2009, 2021; Curtin, 1995; Meier, 1995) in its interaction with Grice's (1975) principles of cooperation. To this end, we examine the ritual of greeting, in particular the exchange of "bonjour" in daily social interactions in a French-speaking context, using an authentic data corpus (Reddit, 2014). The results of our analysis show that, in certain situations, when the symmetry of this ritual is broken and the act fails, French speakers attribute to what is understood as politeness a rating higher than they do to cooperation, giving rise to the opposite phenomenon, impoliteness.
\end{abstract}

KEYWORDS: French interaction, politeness, impoliteness, cooperation, greetings, bonjour.

\section{Introduction}

For centuries, French has been described in a rewarding way, including the beautiful language, the language of love, diplomacy, clarity, and precision, and the most refined of languages. It has also been described as the King's language and as a mirror of French culture. It is the language of the troubadours' courtly literature, and the one that supplanted Latin in national and international relations, as celebrated in Rivarol's renowned speech on its universality. Although these descriptions are intrinsically correlated with linguistic politeness, a concept fundamentally understood as positive social behaviour, in Culpeper's (2009) extensive study of how impoliteness-related terms are used and in his questionnaires asking people about their own use thereof, the term "french" appears twice - alongside "doorman," "bouncer," "bartender," "waitress," "waiter," "yorker," and "staff" - and this in two different categories: one being "subjects regularly described as impolite" and the other suggesting that people evaluate national or 
place-based stereotypes as impolite. In both cases, nearly all of the terms listed relate to public-service contexts, contexts in which people's expectations of cooperation in relation to service entitlements are not always fulfilled or are disputed.

From these facts relating to impoliteness and a lack of cooperation, could one suppose that, in daily interactions in French, the principles of cooperation (Grice, 1975) and politeness come into conflict, leading to the characterization of speakers as impolite? If this is the case, why? How does this occur? Is this characterization specific to public-service contexts or does it extend to other domains of social life?

In attempting to answer these questions, this study evolved within a framework that combines conversation analysis with socio-pragmatic theoretical principles. It comprises three sections: in the first, we describe our understanding of the trajectory of im/politeness, an umbrella term encompassing theories and conceptualizations of both politeness and impoliteness (the trajectory extending from Austin, 1962, to Kerbrat-Orecchioni, 2010, and to Culpeper, 2021).

In the second section, guided by socio-cultural historical factors (Bourdieu, 1984; La Bruyère, 1688), we focus on perspectives on $\mathrm{im} /$ politeness in metropolitan France society. The analysis of a greeting ritual, the exchange of "bonjour," is prioritized in an exploration of the concept of linguistic im/politeness (Culpeper, 2009, 2021; Curtin, 1985; Meier, 1995) in its interaction with Grice's principles of cooperation (1975).

In the third section, we observe that this ritual appears as a micro-interaction: a performative action that sustains relationships between oneself and others in all face-to-face communications. It is how it functions that had led us to inquire about what occurs in interpersonal/intercultural relations in the case of a dysfunction in the dialogue. The results of our analysis demonstrate that, in certain situations, when the symmetry of this ritual is broken and the act fails, French speakers attribute to what is understood as politeness a higher rating than they do to cooperation, giving rise to the opposite phenomenon, impoliteness.

\section{Principles of Linguistic Im/Politeness and Cooperation}

Throughout an extensive literature, the concept of politeness appears as a key element of the socialization process, and great importance has been attached to its teaching, learning, and practice, linguistic and otherwise. Put differently, politeness is not innate; rather, it is an asset constructed in the course of socio-cultural and historical processes. Although there cannot be consensus on its definition, it is fair to posit that, as a positive social behaviour, politeness is fundamentally associated with good manners and is linked to civilization. Writings on politeness as such emerged in the $16^{\text {th }}$ century with Erasmus' (1530) bestseller ${ }^{2}$ on civility, the first treatise in Western Europe on the moral and practical education of children. ${ }^{3}$ As Elias (1982) writes, De civilitate morum puerilium effected a transition to a different standard of behavior, a transition signified by civilité, the term predecessor of civilization in its contemporary sense. In the West, civilite acquired its meaning during the second quarter of the $16^{\text {th }}$ century, when chivalry and the unity of the Catholic Church were losing strength and cohesion and gradually failing. The idea of civilité refers to a social formation which embraces diverse nationalities; it reflects the self-image of members of court society, the new social formation of European nations at the time.

Politeness continued to attract attention during the $17^{\text {th }}$ century with La Bruyère's Characters (Les Caractères, 1688), while in the course of the $18^{\text {th }}$, Burke considered it "more important than laws." Originally formulated by scholars to instruct young princes, the precepts of politeness were later imparted to the sons of the upper classes ${ }^{5}$ before influencing children more generally - followed by their supposedly being sufficiently universal

\footnotetext{
${ }^{1}$ In The Refinement of America: Persons, Houses, Cities (1993), Richard L. Bushman writes that "The whole idea of manners was linked to civilization. It would be listed right along with the growth of art, science and law as a sign that we were civilized" (as cited in Scott, 1998).

2 Originally written in Latin, Erasmus' De civilitate morum puerilium was subsequently translated into numerous languages.

${ }^{3}$ Although the genre has roots in antiquity and the Middle Ages, it emerged decisively only during the Renaissance. See Elias (1982) and "The Earliest Books" (2014).

${ }^{4}$ As cited in Crowe (2012)

${ }^{5}$ On this topic, Scott (1998) observes that "in these pages females are to keep silent. As for dwellers in the countryside, they are too uncouth to mention."
} 
to serve societies themselves. Thus, for almost three centuries, from the Renaissance to the French Revolution, manners were an essential aspect of the ideal of civilization. These courtesy books (an umbrella term) were the literary vectors of the ongoing discussion of morals and of the advocacy of the ideals of character, virtues, habits, manners, and accomplishments - in short, the art of living in society.

From the late $18^{\text {th }}$ and early $19^{\text {th }}$ centuries onwards, however, among scholars this view would change. In $A$ Question of Manners: Status and Gender in Etiquette and Courtesy, Curtin (1985, p. 396) argues that the long association between manners and morals had irrevocably broken, and notes that:

the very fact that the "world" was so full of vain, petty, foolish people made manners essential to the pursuit of self-interest. One learned good manners in order to improve one's chances in a cruel world, not in order to make the world a better place.

Moreover, according to Curtin (1985, p. 402), "the courtesy genre died because the conditions that sustained its difficult compromise between manners and morals did not themselves endure." Thus separated from their context in moral thought and aspiration, "manners were readily dismissed as trivial, formal, mechanical, and hypocritical, unfit either for moralists or for historians" (Curtin, 1985, p. 396). Such a viewpoint is widely shared by scholars, including Davidson (2004, p. 46), who writes that "politeness is a euphemism for something more insidious; politeness means tact, and tact equals lying." It is as if, asserts Curtin (1985, p. 395), scholars had for so long "left manners to the amateurs."

Beginning in the 1970s, the publications of Brown and Levinson ([1978] 1987) inaugurated linguistic politeness studies. While not the first (cf. Lakoff, 1973, 1977; Leech, 1983), their paradigm has endowed the concept with theoretical status. Since then, research on politeness phenomena has been held to be "one of the most important and productive areas of research in pragmatics and sociolinguistics" (Preisler \& Haberland, 1994, p. 227). In the words of O'Driscoll (2007a, p. 465), Brown and Levinson's "great achievement has been to put socio-pragmatic concerns at the forefront of pragmatic research and the affective aspects of communication firmly on the pragmatics map."

Rooted in Gricean pragmatics ${ }^{7}$ and traditional speech act theory (cf. Austin's and then Searle's works), Brown and Levinson's paradigm considers two types of politeness strategies, negative and positive face, framed within Goffman's notion of face (1967, p. 13):

The members of every social circle may be expected to have some knowledge of face-work and some experience in its use. In our society, this kind of capacity is sometimes called tact, savoir-faire, diplomacy, or social skill. Variation in social skill pertains more to the efficacy of face-work than to the frequency of its application, for almost all acts involving others are modified, prescriptively or proscriptively, by considerations of face.

In the post-Brown-Levinson era, while pragmatics remains the conceptual heart of the field, models of politeness have been applied and often refined across disciplines. Culpeper $(2013$, p. 3) observes that "there are ... important spin-offs for other disciplines, including social psychology (especially related to verbal aggression), sociology (especially related to verbal abuse), conflict studies (e.g. resolution of verbal conflict) and media studies (e.g. exploitative TV)." In short, together, the classical pragmatic view and the socio-cultural approach of linguistic politeness represent the two great periods of politeness literature.

Since it has become clear (see Mills, 2015) that each society has a particular set of social norms comprising more or less explicit rules that prescribe a certain behaviour, state of affairs, or way of thinking in a certain context, scholars have argued for the classical model's rejection and/or revision-while at the same time developing alternative models. For Kasper (1990, p. 1),

\footnotetext{
${ }^{6}$ In this vein, seven of the most cited articles published by the Journal of Pragmatics involve politeness and related subfields (see https://www.journals.elsevier.com/journal-of-pragmatics). The field also has its own dedicated journal, namely the Journal of Politeness Research (https://www.degruyter.com/view/j/jplr), which is associated with the international Linguistic Politeness Research Group (established in 1998; https://linguisticpoliteness.wordpress.com/about-2/affiliated-groups/).

7 See Part 3.
} 
together with other politeness models, notably Lakoff's $(1973,1975)$ and Leech's (1983), Brown and Levinson's theory has partly been supported by the literature. However, in the light of current evidence, it has also become clear that the early models, while impressive in their parsimony and elegance, are over-simplistic. Their lasting achievement is to have provided excellent heuristics to investigate a highly complex object of inquiry.

Among the most criticized aspects of Brown and Levison's theory is the face-threatening act (FTA). In "What's in an FTA?" O'Driscoll (2007b, p. 243) observes that "no act is intrinsically face-threatening and that FTAs cannot be equated with speech acts. They can only be identified in the context of the ongoing interaction." O'Driscoll (ibid.) suggests that an FTA "is simply any move which predicates a change in face. However, its ultimate identification rests with interactants." According to his study, the severity of an FTA is the product of two factors: the amount of face-change it predicates and the amount of salience accorded to face at the time. However, the values of these factors are ultimately determined by participant reactions. Further here, both of these matters are addressed largely through close examination of one particular moment in one particular encounter.

In order "to make [the classical model] more efficient," Kerbrat-Orecchioni (2010, p. 35) suggests three major improvements: recognition of face-flattering acts (FFAs) alongside FTAs; in addition to the politeness/impoliteness couplet, the introduction into the system of categories such as "overpoliteness," "non-politeness," and "polirudeness;" ${ }^{8}$ and a more profound reflection on the phenomena of impoliteness.

Regarding the last point, recent developments in the field indeed indicate "a certain shift in interest in politeness towards impoliteness" (Kerbrat-Orecchioni, 2010, p. 38). In this respect, Sifianou (2010, p. 119) writes that

The year 2008 could be referred to as "the Year of Impoliteness." The appearance of a book [Bousfield's Impoliteness in Interaction] and [an] edited volume [Bousfield and Locher (eds): Impoliteness in language: Studies on its interplay with power in theory and practice], and two special journal issues (Journal of Politeness Research 4.2 and Pragmatics 18.4) cannot be a mere coincidence. Such proliferation is the bumper harvest of pleas by many scholars that the study of impoliteness deserves attention.

From 2002 to 2018, twenty-one conferences were devoted to the topic. ${ }^{9}$ Since 2009, the subject has also benefited from the presence of Culpeper's (2009) website, Impoliteness: Using and Understanding the Language of Offence, which focuses "on language that is generally considered anti-social, and is labelled by a wide-range of terms such as impolite, rude, inconsiderate, verbally abusive, etc."

Since then, theoretical considerations and conceptualizations relating to both politeness and impoliteness have included terminological issues (Culpeper, 2009, 2021), the distinction between first- and second-order politeness (see Watts, 2003; Bousfield \& Locher, 2008), the notion of face, ${ }^{10}$ the concept of relational work (see Locher \& Watts, 2008), and intercultural/intracultural issues, which have in turn spurred the recent arousal of interest in another dimension of im/politeness in verbal interactions: the emotional constituent; for example, Wierzbicka (1999) on the conceptualization of emotions across languages and cultures; Blum-Kulka and Olshtain (1984) and Blum-Kulka et al. (1989) on the notion of involvement; de Oliveira's (2013, 2015) studies of im/ politeness and emotions in the French and Portuguese (Brazil) languages; and Moïse (2019) on verbal violence and the function of insult."

As observed, as far as im/politeness is concerned, both the classical model and the subsequent literature testify, through the multidisciplinary nature of the subject, to a troubling amount of divergence and/or vagueness regarding the meaning of the concept and concomitant concepts "both across studies and within the same

\footnotetext{
${ }^{8}$ See further Data and Method Analysis section.

${ }^{9}$ Full conference details listed by the Linguistic Politeness Research Group are available at https://linguisticpoliteness.wordpress.com/ conferences

10 In Chapter 3 of Impoliteness in Interaction (2008), Bousfield explores the significance of "face" in the study of politeness and human interaction and discusses how the dualism of negative and positive face has been exploited in politeness research.

${ }^{11}$ On this point, also see Galatanu, Bellachhab \& Cozma (2014).
} 
studies" (Meier, 1995, p. 345). Although it is indisputable that cooperation does not occur in an identical manner in all societies, researchers (see, e.g., Meier, 1995) continue to warn of the dangers of the claim to im/politeness universals (which has led to ethnocentric attempts to determine standards applying to all groups) and to remind us that one of the main purposes of socio-pragmatics is to discover how different societies deal with maxims in different ways.

In the next section, we provide insight into im/politeness in French society with the aim of understanding what has led people to associate "French" with impolite terms.

Views on SocioCultural Principles of French Politeness
Examining as it does various judgments of im/politeness in French society, La Bruyère's (1688) approach to politeness in Characters ${ }^{12}$ is of great historical and contemporary socio-cultural interest.

A summary of Characters by the author ${ }^{13}$ himself reads:

Of the sixteen chapters which compose it, there are fifteen wholly employed in detecting the fallacy and ridicule to be found in the objects of human passions and inclinations, and in demolishing such obstacles as at first weaken, and afterwards extinguish, any knowledge of God in mankind; therefore, these chapters are merely preparatory to the sixteenth and last, wherein atheism is attacked ..., wherein the providence of God is defended against the insults and complaints of freethinkers. ${ }^{14}$

Despite the moral tone perceptible in his words, in declaring that he "did not wish to write any maxims, for they are like moral laws" and acknowledging that he possessed "neither sufficient authority nor genius for a legislator," 15 La Bruyère distanced himself from the role of speculative moralist and appears as an observer of individual manners. Nonetheless, as Van Laun (1885, p. 13) suggests:

[La Bruyère] was the first to make morality attractive, and to paint characters in a literary and delicate manner; he does not dogmatise, and above all shows neither personal hatred nor venom; in other words, to use his own expression, he "gives back to the public what it lent" him.

Such is also the viewpoint of Barthes (1972, p. 222), for whom La Bruyère is

a moderate moralist, he does not scald (except perhaps in the chapters on women and money, of an unyielding aggressiveness); and furthermore, although an avowed painter of a society and, within that society, of the most social passion there is, worldliness, La Bruyère does not become a chronicler, a Retz or a Saint-Simon; ... as a moralist, he persistently refers to a real society, apprehended in its persons and events.

In La Bruyère's conceptualization, one may define all the essentials of politeness, but no one can determine how and where they should be used. Put another way, politeness depends on ordinary habits and customs, relates to times and places, and varies according to gender and social rank. Moreover, as La Bruyère (1688) stresses, "intelligence alone cannot find this out: politeness is acquired and perfected by imitation. ${ }^{16}$

In addition, the $17^{\text {th }}$ century author warns that "politeness does not always inspire goodness, equity, complacency, gratitude; it shall give at least the appearance and makes the man appear outwardly as he ought to be inside."17

12 The editorial saga involving this work, with eight editions revised and extended in the course of the lifetime of its author, provides the measure of its immense success. Enriched and completed over the years, the collection is the work of a lifetime -420 remarks in 1688; 1120 in 1694 - and the only one that La Bruyère published. He was still working on the ninth edition at the time of his death in 1696.

13 Preface to La Bruyère's "Speech upon his Admission as a Member of the French Academy, June 15, 1693", which was published for the first time with the eighth edition of Characters in 1694; as cited in Van Laun's (1885, p. 12) introduction to his translation.

${ }^{14}$ La Bruyère's work was inspired by his translation of Theophrastus (a 4th century BC writer) in 1688.

15 Preface to La Bruyère's Characters, as cited in Van Laun (1885, p. v).

16 “L'on peut définir l'esprit de politesse, l'on ne peut en fixer la pratique: elle suit l'usage et les coutumes reçues; elle est attachée aux temps, aux lieux, aux personnes, et n'est point la même dans les deux sexes, ni dans les différentes conditions; l'esprit tout seul ne la fait pas deviner: il fait qu'on la suit par imitation, et que l'on s'y perfectionne."

17 “La politesse n'inspire pas toujours la bonté, l'équité, la complaisance, la gratitude; elle en donne du moins les apparences, et fait paraitre l'homme au dehors comme il devrait être intérieurement." 
From this point of view, politeness appears to be a mask and, as such, it likely hides a hypocritical essence. Yet, in the practice of politeness, sincerity does not seem to be of particular importance. For de Mourgues (2010, p. 166), it is clear ... that for La Bruyère virtue and politeness do not necessarily go together:

"Avec de la vertu, de la capacité, et une bonne conduite, l'on peut être insupportable. ${ }^{18}$ ("Of society," 31).

Neither do intelligence and refinement of manners:

"La grossièreté, la rusticité, la brutalité peuvent être les vices d'un homme d'esprit." ments," 48).

Nevertheless, La Bruyère (1688) also argues that "politeness tends, undoubtedly, to advance merit and to render it agreeable; a man must have very eminent qualities to hold his own without being polite. ${ }^{20}$ We would add that, actually, "it is allowed to be thought that politeness is the condition of survival in society and the survival of societies" (Kerbrat-Orecchioni, 2015).

In this sense, it seems fair to posit that, since La Bruyère's characters are apprehended within an actual society, in its persons and events, and are portrayed in a literary and delicate manner, his viewpoints on social politeness tend to appear morally attractive.

Two decades into the $21^{\text {st }}$ century, it is of interest to observe the relevance of La Bruyère's principles of politeness in present-day society. To demonstrate this, in what follows, we examine the ritual of greetings, focusing on the normatively symmetrical exchange of "bonjour" in daily social interactions and on the extent to which this formula is used as a formal, codified expression.

\section{Routine Greeting Rituals: Foundations}

The term ritual comes from the Latin, ritus, meaning "prescribed order." Numerous social rituals are born

in the great historical influences with which a people were impregnated and conditioned culturally from childhood. Ritualization has gradually taken hold, and the postures and words that accompany it have become the Norm. Numerous superficial variations, evolutions, revolutions, cyclical rejections, inventions ... can affect this norm, but nothing, I believe, calls into question its founding principles (Cortès, 2007, p. 154). ${ }^{21}$

In Politesse, savoir-vivre et relations sociales, Picard (2014, p. 48) establishes a link between politeness and ritual, which the author defines as follows:

[Rituals are] repetitive and quasi-automatic acts which can never be reduced to simple operational acts, being charged with a strong symbolism and being based on an adherence to social and cultural values, ... rituals participate fully in institutional systems, from which they emerge. ${ }^{22}$

Accordingly, the fundamental characteristics of the ritual of politeness are its mechanical dimension, its symbolic character, and its institutional aspect.

\footnotetext{
18 "With virtue, ability, and good behaviour, one can be unbearable."

19 "Coarseness, rusticity, and brutality can be the vices of a man of wit."

20 "Il est vrai que les manières polies donnent cours au mérite, et le rendent agréable; et qu'il faut avoir de bien éminentes qualités pour se soutenir sans la politesse."

21 "Dans les grandes influences historiques dont un peuple a été imprégné et conditionné culturellement dès l'enfance. La ritualisation s'est installée progressivement et les postures et mots qui l'accompagnent sont devenus la Norme. Des variations de surface nombreuses, des évolutions, des révolutions, des rejets conjoncturels, des inventions ... peuvent affecter cette norme mais rien, je crois, ne remet en cause ses principes fondateurs."

22 "Actes répétitifs et quasi-automatiques, ne pouvant jamais se réduire à de simples actes opératoires, ayant une forte charge symbolique et s'appuyant sur une adhésion à des valeurs sociales et culturelles, ... les rituels participent pleinement au système institutionnel, dont ils sont issus."
} 


\section{The Case of "bonjour"}

In terms of its mechanical dimension, the exchange of "bonjour" both inside and outside the family circle is a repetitive and quasi-automatic act learned or mimicked - in any case, internalized - very early on by French speakers.

This mechanical dimension "is what guarantees the system of social relations a predictability, saving society from many conflicts" (Mejri, 2017, p. 20). ${ }^{23}$ This is because the successful exchange of "bonjour" is capable of "transforming conflicts into symbols by ordering and integrating them into pre-established scenarios" (ibid.). ${ }^{24}$

At the symbolic level, according to Mejri's definition, respect for these scenarios guarantees "relations presenting the minimum of conflict and the maximum of respect between one another, respect inscribed in the values that the system erects in rituals" (2017, p. 20). ${ }^{25}$

These mechanical and symbolic characteristics of the "bonjour" exchange are inseparable from its institutional function, the role of which is to ensure that language users learn, accept, apply, and thus maintain ritualized greeting rules.

To encapsulate these characteristics of this ritual, we suggest the concept of a "trademark," as introduced by Bourdieu (1984, p. 65) in "Manners and Manner of Acquisition":

Cultural (or linguistic) competence, which is acquired in relation to a particular field functioning both as a source of inculcation and as a market, remains defined by its conditions of acquisition. These conditions, perpetuated in the mode of utilization-i.e., in a given relationship to culture or language-function like a sort of "trade-mark," and, by linking that competence to a particular market, help to define the value of its products in the various markets.

In the next section, we show that despite the constraints experienced during the socialization process, having reached adulthood, French speakers themselves adhere to the transmission of the "bonjour" ritual by valuing the act of greeting not, or no longer, as an imposed behavioural rule but as a savoir-vivre à la française, a trademark. In this sense, we can refer to its performativity, as defined by Butler, that is, as "that reiterative power of discourse to produce the phenomena that it regulates and constrains" (1993, p. xii).

\section{Socio-Cultural Trademark}

As a performative act, the trademark of politeness, "bonjour," requires neither spontaneity nor sincerity. Its symmetrical parameterization presents the interaction - what in interactional linguistics is referred to as action and reaction - as a network of mutual influences. As we will see further, given its high degree of ritualization, any dysfunction poses a threat to the collective identity both within and outside the collectivity.

The situation described below, in which a child is reprimanded for not greeting someone, is a familiar French cultural scene that illustrates the socialization process of the bonjour exchange. As formulated by the parents, the reprimand is generally manifested in the injunction, "Say 'bonjour' to the lady/gentleman;" when uttered by the one being "ignored," the blame (whose joking tone cannot hide the reproach) is manifested in, among other versions, "So, have we lost our tongue?"/“Don't we say "bonjour' to grandma anymore?" In either case, what one wants to make clear to the child is that $\mathrm{s} /$ he has committed an error and that, for this error to be repaired, $\mathrm{s} / \mathrm{he}$ must say the word "bonjour." If the child maintains his/her position (among other things, because s/he is tired or distracted) and refuses to perform the ritual, $\mathrm{s} / \mathrm{he}$ is told that $\mathrm{s} / \mathrm{he}$ is not being gentle, that $\mathrm{s} / \mathrm{he}$ is not being polite; or else $\mathrm{s} / \mathrm{he}$ is told that $\mathrm{s} / \mathrm{he}$ is gentle and polite therefore s/he says "bonjour" to the lady/gentleman.

An etymological overview of the qualifier "gentle" reminds us that it means "of noble origin" or "noble in behaviour," while "polite" denotes "civilized". Since negotiating power in an interaction is part of how interactants shape and present their identity, the semantic circularity maintained by these qualifiers (gentle/noble/polite/ civilized) reveals the gratifying profile of those who bow to - in the sense of adhere to - the ritual of "bonjour".

23 "C'est ce qui garantit au système des relations sociales une prédictibilité économisant à la société bien des conflits."

24 "Transformer les conflits en symboles en les ordonnant et en les intégrant dans des scénarios préétablis."

25 "Des relations présentant le minimum de conflit et le maximum de respect entre les uns et les autres, respect inscrit dans les valeurs que le système érige en rituels." 
However, to adhere to does not necessarily mean to comply with the "bonjour" symmetry. This can be illustrated by means of a situation observed in a university faculty office where several people - all of them students queue to obtain administrative academic information. Approaching the counter behind which $B$ (the secretary) sits, A (a student) says "bonjour" to B, who, while continuing her activities and without looking up, answers, "Oui, c'est pourquoi?" (Yes, what's that for?"). A, visibly somewhat disconcerted, then turns to the audience in the room (as if looking for support) before turning back to B, who then answers A's question without making eye contact. It is of interest to note that, for the time we observed this scene, there was no instance of someone from the public (identified as a student) who failed the exchange. Thus, we concur with Bousfield (2008) that impoliteness is tied to the concept of power.

In support of Bourdieu's (1984) work, we postulate that B's linguistic (and non-linguistic) behaviour is linked to her role as an "authorized spokesperson" who represents the cultural capital ${ }^{26}$ accumulated by the group that commissioned her and of which she is the representative. As a result, $B$ is invested with a symbolic power which is constitutive of her (or, of this sort of) position, which enables her to decide on and impose her own behaviour. Introduced by Bourdieu to account for the tacit, almost unconscious modes of cultural and social domination that occur in daily social habits (illustrated here by a greeting ritual), the concept of symbolic power also ensures the placement of individuals invested with it in a social hierarchy, in individual relationships and in social institutions. In terms of pragmatics values, Culpeper (1996, p. 35) suggests that "powerful interlocutors"

a Reduce the ability of the less powerful participant to retaliate with impoliteness.

b Threaten more severe retaliation should the less powerful participant be impolite.

In brief, in interactions in a network of mutual influence, any action and reaction are related to the interlocutors' power: more powerful interlocutors have more freedom to be impolite. If symbolic power (Bourdieu, 1984) requires a dominator (adults, in our examples above), it also requires the dominated (children and students in our examples above) who submit themselves to or who accept their position in the exchange of social value that occurs between them (e.g., the children) and adults, or in the exchange of services, including the transmission of information (e.g., the student).

In the next section, we develop the view that the central meaning of power surely involves a conflict of interests rather than a consensus (Watts, 1991). Having seen, above, that a conflict of interests is particularly evident when there is an imbalance of power ${ }^{27}$ between interlocutors, we demonstrate how such an imbalance of power leads to impoliteness.

We may summarize the issue by stating that when interlocutors do not agree on a matter, they mostly threaten each other's face; this being the case, there is a good possibility of their being impolite in order to convince each other.

\section{Data and Method Analysis}

\section{Data Corpus ${ }^{28}$}

The data analysed here are sourced from Reddit (cf. "read it," i.e. "I read it on Reddit"), a social news platform comprising user-generated content, such as photos, videos, links, text-based posts, and discussions of content in what is essentially a bulletin-board format. In 2018, there were approximately 330 million Reddit users, known as "redditors". The site's content is divided into categories or communities known on-site as "subreddits", of which more than 138,000 are active.

\footnotetext{
${ }^{26}$ According to Bourdieu (1986, p. 17), "Cultural capital can exist in three forms: in the embodied state, i.e., in the form of long-lasting dispositions of the mind and body; in the objectified state, in the form of cultural goods (pictures, books, dictionaries, instruments, machines, etc.), which are the trace or realization of theories or critiques of these theories, problematics, etc.; and in the institutionalized state, a form of objectification which must be set apart because ... it confers entirely original properties on the cultural capital which it is presumed to guarantee."

${ }^{27}$ Culpeper (1996) writes that investigating the factors involved in the occurrence of impoliteness in the case of equal relationships is extraordinarily complex.

28 Information on Reddit is drawn primarily from three sources: the Reddit web page: https://www.reddit.com/, Wikipedia: https:// en.wikipedia.org/wiki/Reddit\#cite_note-Molina17-24, and Wired: https://www.wired.com/story/reddit-redesign/
} 
As a network of communities, Reddit's core content consists of posts by its users, who can also comment on others' posts in order to continue a conversation. The number of upvotes (positive votes) or downvotes (negative votes) determines the posts' visibility on the site; hence, the most popular content is displayed to the greatest number of people. The most popular posts from the site's numerous subreddits are visible on its front page for those who browse it without an account. For such users, the front page by default displays the subreddit, r/popular, which features the top-ranked posts across Reddit. Front-page rank - for both the general front page and for individual subreddits - is determined by a combination of factors, including the age of the submission, the positive ("upvoted") to negative ("downvoted") feedback ratio, and the total vote count.

In terms of user profiles, Reddit seems to be browsed primarily by English speakers, mainly from the United States. Thus, according to Alexa statistics (October 6, 2018), 60.6\% of its traffic comes from the US (where, at the time, Reddit was the $5^{\text {th }}$ most popular site). This is far ahead of the United Kingdom, which comes in second (7.0\% of Reddit traffic and $8^{\text {th }}$ in terms of popularity), Canada (6.3\% of traffic, but the $5^{\text {th }}$ most popular site), and then Australia (3.2\% of traffic) and Japan (1.9\% of traffic). In mid-2018, again according to Alexa, Reddit was the $17^{\text {th }}$ most visited site in France and the $7^{\text {th }}$ most-visited worldwide (behind Google, YouTube, Facebook, Baidu, Wikipedia, Yahoo, and QQ). On October 6, 2018, traffic on Reddit came mainly from Google (16.4\% of cases), and then from YouTube (8.3\%), Facebook (5.0\%), Twitter (3.4\%), and Imgur (3.0\%). The amount of time spent on the site per visitor is among the highest of similar platforms, according to the same source, with a daily average of 11 minutes and 36 seconds at the start of 2019. The communities or subreddits bring people and their interests together. These subreddits range in topic from the teaching of languages to juggling and include controversial topics, such as how to order a coffee in France.

\section{Method of Analysis}

The starting point of our work was the following display on the menu board of a French coffee shop:29

Un café. "A cup of coffee." € 7.00

Un café, s'il vous plait. "A cup of coffee, please." $€ 4.25$

Bonjour, un café, s'il-vous-plait. "Good morning, a cup of coffee, please." $€ 1.40$

The image of this board, ${ }^{30}$ recorded in photos by clients and posted on various social networks, made its way around the web, triggering around 4000 comments $^{31}$ from French nationals, French speakers, and foreign Internet users. ${ }^{32}$ Our qualitative analytical approach to the initial corpus takes into account the first 400 reactions, that is, approximately $10 \%$ of the data collected, archived, and available for the original post on the Reddit platform. ${ }^{33}$ Other Internet users' testimonies from other sources are also considered.

At first glance, the board seems to function as a reminder to customers (native speakers or not) who, for some reason, do not use prescribed sequences constructed according to strict and rigid procedural rules. Expressions of procedural meaning (EPMs), ${ }^{34}$ such as greetings (here, bonjour) and requests (s'il-vous-plait), are indeed required in requests and/or commands (as in the situation described above): their content is backgrounded; only their functional role matters. In other words, these words and expressions have been pragmaticized. However, non-native speakers may not have or not use the same range of EPMs as French speakers because they have

\footnotetext{
29 "Bonjour, un café" (2014); Lestz (2014).

${ }^{30}$ As revealed by Le Parisien on March 13, 2016, the original post by an Internet user, titled "On a retrouvé le respect/We have regained respect” was retweeted 17,200 times. https://twitter.com/harrylafranc/status/705000927976103936?ref_src=twsrc\%5Etfw\%7Ctwcamp\% 5Etweetembed\%7Ctwterm\%5E705000927976103936\%7Ctwgr\%5E\%7Ctwcon\%5Es1_\&ref_url=https\%3A\%2F\%2Fwww.huffingtonpost. fr\%2F2016\%2F03\%2F03\%2Fprix-cafe-politesse-restaurant-francais_n_9372238.html

${ }^{31}$ According to Le Parisien of March 13, 2016. On March 3, 2016, the Huffington Post had already reported about 3,500 Internet users. https://www.huffingtonpost.fr/2016/03/03/prixcafe-politesse-restaurant-francais_n_9372238.html

32 Since then, different versions of the original have been found around the Internet.

33 Reddit (Note that this thread is archived. Users have not been able to post new comments or cast votes since 2016.) https://www. reddit.com/r/pics/comments/48Ivnl/un_caf\%C3\%A9/

${ }^{34}$ On EPMs, see Watts (2003).
} 
not undergone the same process of socialization. Indeed, some non-French speaking cultures have similar EPMs, but they do not have the same pragmatic values. Given that each language, and thus each community, has its own pragmatic rules and contexts in which these are applied, the information on the board may appear to be an attack, one that warns customers of penalties to be imposed in case of non-compliance with the rules.

The message displayed on the board does not follow Grice's cooperative principle of "make your conversational contribution as required, at the stage at which it occurs, by the purpose or accepted direction of the conversation exchange in which you are committed" (1975, p. 45), nor his four maxims of cooperation. The information provided does indeed not "tell the truth or something that can be proven by adequate evidence" (the quality maxim); by "saying" more than expected, the message is not as informative as is required (the maxim of quantity); therefore, the information is irrelevant to the subject of the situation (the maxim of manners); for these reasons, the message is perceived as being ambiguous and/or obscure (the relation maxim) (Grice, 1975). However, as we may observe from the examples that follow, what at a first glance is susceptible to being considered a lack of respect for cooperative principles and maxims turns out to be a strategy to otherwise promote the application of rules of politeness or, at least, to make them known, as in (a) below:

a "Is this initiative [i.e., prices calculated based on a client's politeness] a good idea? 'This is precisely the spirit of French coffee,' claims Pierre Boisard, sociologist, author of La Vie de bistrot." 35

Indeed, the initiative that involves educating costumers is described as a positive one due to its societal value: appreciation of the spirit of "French cafés". In other words, people should understand the manner in which the spirit of French cafés is intended to work. In (b), it is clear that there is a distinction between "regulars" and "others":

b "The regulars greet us, so we take that into account. But some tourists who arrive in summer do not respect us, and when we hear 'Coffee!' 250 times, it makes us grumpy. They should not be surprised to receive a slightly higher bill." (Opinion of a restaurateur) ${ }^{36}$

As observed in (b), people position themselves as the guardians of the spirit of French cafés, valuing those who greet them and punishing those who fail to say "bonjour." This failure is seen as impolite not only because it incompatible with a societal habit but also because the exchange is supposed to function as a balance in relation to the volume of coffee orders in the course of a repetitive work routine. This may also be observed in (c), where the implementation of the exchange appears as key to saving French cafés or at least to stopping their progressive disappearance:

c "Nothing prevents ... friendliness from being a criterion. ... It is a nod among others to remind us that cafés are places of sociability. And they really need it, having gone from 200,000 to less than 35,000 in fifty years." (Roland Héguy, president of the union of hotel trades and industries $)^{37}$

A moral tone is perceptible when an opinion suggests that the decrease in the number of French cafés reflects a decline in politeness, which should be prevented, as in (d):

d "It's a system we would do well to adopt in places other than in restaurants. If impolite individuals deviate from conventional formulas of human interaction, we should let them know." 38

\footnotetext{
35 a. "Ce[tte] initiative ... [est-elle] une bonne idée ? "C'est justement l'esprit du café à la française, défend Pierre Boisard, sociologue, auteur de la Vie de bistrot" https://www.leparisien.fr/archives/c-est-combien-le-cafe-ca-depend-de-votre-politesse-13-03-2016-5621387.php

36 b. "Les habitués nous saluent, donc on en tient compte. Mais certains touristes qui arrivent en été ne nous respectent pas, et quand on entend 250 fois 'café!' ça nous rend grognons. II ne faut pas qu'ils s'étonnent après d'avoir une addition un peu salée." (Avis d'un restaurateur) https://www.leparisien.fr/archives/c-est-combien-le-cafe-ca-depend-de-votre-politesse-13-03-2016-5621387.php

37 c. "Rien n'empêche ... l'amabilité d'être un critère ... C'est un clin d'œil parmi d'autres pour rappeler que les cafés sont des lieux de sociabilité. Et ils en ont bien besoin, eux qui sont passés de 200,000 à moins de 35,000 en cinquante ans." (Roland Héguy, président de l'Union des métiers et des industries de l'hôtellerie) https://www.leparisien.fr/archives/c-est-combien-le-cafe-ca-depend-de-votrepolitesse-13-03-2016-5621387.php
} 
As an index of politeness, the application of conventional formulas should be preserved not only in restaurants but everywhere:

e "It's about having respect for the staff. Not so much about being able to speak (or even really attempt to) speak French. The French have quite a formal system of greeting each other and they all expect to be treated the same, from shopkeepers to doctors and the like (Égalité and all that). A friendly "Bonjour" will go far in the majority of cases. Source: I live there." 39

Such testimonies lead to the observation that when the symmetry of the exchange is broken, French speakers rate what is understood as politeness, that is, formal use of EPMs, higher than they do cooperation. Put another way, cooperation (here involving serving someone a cup of coffee) depends on the application of linguistic tools of politeness. In this regard, at least three essential functions of this ritual emerge: it is an issue of marking respect through a constant search for balance based on to the nature of the relationship, which, in this instance at least, helps preserve social ties (see Picard, 2014). Saying "bonjour" thus involves doing something; in Austin's terminology, saying "bonjour" is a performative utterance or a performative act. From this perspective, the "bonjour" greeting incorporates the typology of what Kerbrat-Orecchioni $(1995, \mathrm{p}$. 72) calls relationèmes, that is to say, elements "to be considered both as indicators and as constructors of the interpersonal relationship." Thanks to a thoroughgoing, secular process of socialization (cf. socio-cultural trademarks), this relationème emerges not only as a "bon usage" but as the only "bon usage."

On the other hand, non-native speakers (especially those who have not undergone exactly the same socialization process) may not know or use the same range of EPMs as native speakers of French. Since each language or community has its own pragmatic rules and contexts in which they are applied, the information displayed on the board, namely the price of coffee based on customers' manners, looks like an attack because it warns customers of the penalties to be imposed in the case of non-compliance with the rules. Reactions to this positioning may involve astonishment (i):

i "Don't get it. Why is there variance in the price?"40

ii "Haha, manners...."

iii "Well, isn't that nice!"42

iv "I wonder what would happen ... if you said 'hello, sorry to bother you, but I wonder if you could bring me a coffee, I would be eternally grateful to you...'. [Would] you pay?"43

v "I have French co-workers I have to deal with. When they piss me off, I will go about a week without any greetings. It's my passive aggressive loathing of them. They are actually really cool, but I laugh out loud when I don't send a greeting."

vi "I'd order the expensive one every time. Fuck their patronizing attitude." ${ }^{44}$

These reactions illustrate different forms of the defiant attitudes of Internet users regarding the perceived threat, namely astonishment (i) and boredom (iii), as well as irony linked to social criticism (iv, v, vi) and sarcastic mockery (ii, iv), which fall into the category of over-politeness. As a result, what is said falls between what is appropriate

38 d. "C'est un système que nous ferions bien d'adopter ailleurs que dans les restaurants. Si des individus impolis dérogent aux formules conventionnelles d'interaction humaine, nous devrions le leur faire savoir." (Anonymous, Reddit) https://www.reddit.com/r/ learnfrench/comments/48mtjw/un_café_xpost_from_rpics/

39 e. https://www.reddit.com/r/pics/comments/48Ivnl/un_caf\%C3\%A9/

40 i. https://www.reddit.com/r/pics/comments/48Ivnl/un_caf\%C3\%A9/

41 ii. https://www.reddit.com/r/learnfrench/comments/48mtjw/un_caf\%C3\%A9_xpost_from_rpics/

42 iii. https://www.reddit.com/r/learnfrench/comments/48mtjw/un_caf\%C3\%A9_xpost_from_rpics/

43 iv. "Je me demande ce qui se passerait ... si vous disiez 'bonjour, désolé de vous déranger, mais je me demande s'il vous serait possible de m'apporter un café, je vous en serais éternellement reconnaissant.... Vous pay[eriez]?” https://www.reddit.com/r/pics/ comments/48Ivnl/un_caf\%C3\%A9/

44 vi. https://www.reddit.com/r/pics/comments/48Ivnl/un_caf\%C3\%A9/ 
and what is not, which makes it less than polite-and it can mostly be observed to be impolite (e.g. iv, v, vi). Alternatively, rather than being an indicator of impoliteness, over-politeness may simply represent failed attempts at politeness or be intentionally used and/or perceived to be intentionally used to create a negative effect (iv).

\section{Final Considerations}

Under the generic category of courtesy books (on English manners), the precepts of politeness were first used to educate royal children. Developed by scholars (see Erasmus, 1530; La Bruyère, 1688), they were then addressed to the sons of the wealthy classes, before influencing all children and being supposedly sufficiently universal to serve societies themselves (see Picard, 2014).

From the Renaissance to the French Revolution, manners were an essential aspect of the ideal of civilization. These so-called courtesy works were the literary vectors for discussions of diverse subjects and concepts, such as morality, the defence of ideals of character, virtues, habits, manners, and accomplishments in short, everything relating to the art of living in society.

Since then, beyond its prescriptive nature, the exchange of greetings, such as the ritual of "bonjour," which we see as a trademark of politeness, has echoed a system of traditional values that are respected and rewarded (see Bourdieu, 1984), and through which collective identity is maintained.

Qualitative analysis of the data corpus suggests that, in France, the polite "bonjour" remains a foundational contemporary value that French speakers strive to defend whatever the consequences, including their being considered impolite.

From impoliteness that is linked to power differentials (see Culpeper, 1996) emerges a provocative thesis, namely that there is no and can be no interaction without power and that impoliteness is an exercise in power. As it tends to have (or might always have) an effect on how we address others, it involves a conflict of interests rather than a consensus (Watts, 1991). As we have attempted to demonstrate in this study, this conflict of interests is generated by an imbalance of power: since those involved do not agree on the subject of the rules of greeting, they threaten each other's faces, risking impoliteness in order to convince the other of their views.

However, a face (the customer's) damaged by an utterance generated by speakers invested with symbolic power (the price of a coffee aligned with a customer's manners) finds its options for response limited. Expressed differently, one should accept that, for the sake of cooperation - and contrary to the infamous saying - in France, without a "bonjour," the customer is not always right.

Acknowledgement

This publication is based on research that has been supported in part by the University of Cape Town's Research Committee (URC).

The author is grateful to her English-language editors Carl Becker and Richard Bowker for their work in improving the linguistic cohesion of this paper.

\section{References}

1 Austin, J. L. ([1962] 1970). Quand dire c'est faire. Paris : Éd. du Seuil.

2 Barthes, R. (1972). Critical Essays. Translated from the French [Essays critiques] by Richard Howard. Evanston, II: Northwestern University Press.

3 Blum-Kulka, S., \& Olshtain, E. (1984). Requests and apologies: A cross-cultural study of speech act realization patterns (CCSARP). Applied Linguistics, 5(3), 196213.https://doi.org/10.1093/applin/5.3.196

4 Blum-Kulka, S., House, J., \& Kasper, G. (1989). Cross-cultural Pragmatics: Requests and Apologies. Norwood, NJ: Alblex Publishing Corporation.
5 Bonjour, un café, síl-vous-plait (2014, July 18) [blog post]. Retrieved from: https://saliannefrenchfocus.wordpress.com/2014/07/18/ bonjour-un-cafe-sil-vous-plait/.

6 Bourdieu, P. (1984). Distinction. A Social Critique of the Judgement of Taste. Translated by Richard Nice. Cambridge, MA: Harvard University Press.

7 Bourdieu, P. (1986). The Forms of Capital. In Richardson, J. (Ed.), Handbook of Theory and Research for the Sociology of Education (pp. 241-58). Westport, CT: Greenwood.

8 Bousfield, D. (2008) Impoliteness in Interaction. Amsterdam: John Benjamins. https:// doi.org/10.1075/pbns.167 
9 Bousfield, D., \& Locher, M. A. (2008) (Eds.), Impoliteness in Language. Studies on its Interplay with Power in Theory and Practice (pp. 77-99). Berlin \& New York: Mouton de Gruyter. https://doi. org/10.1515/9783110208344

10 Brown, P., \& Levinson, S. C. (1987). Politeness: Some Universals in Language Usage. Cambridge: Cambridge University Press. https://doi.org/10.1017/CBO9780511813085

11 Butler, J. (1993). Bodies that Matter: On the Discursive Limits of Sex. London and New York: Routledge.

12 Cortès, J. (2007). "Mouche ton nez, dis bonjour à la dame!" Réflexions didactologiques sur la politesse et sur sa vision spéculaire, I'hypocrisie. Synergies Monde, 3, 2008, 147-159.

13 Croce, P. (1997). A brief history of manners. In The public perspective, December/January 1997. Retrieved from: https:// ropercenter.cornell.edu/public-perspective/ ppscan/81/81066.pdf

14 Crowe, I. (2012). Edmund Burke and Manners. Retrieved from: http://www.theimaginativeconservative.org/2012/12/edmundburke-on-manners.html

15 Culpeper, J. (1996). Towards an anatomy of impoliteness. Journal of pragmatics, 25(3), 349-367. doi: 10.1016/0378-2166(95)00014-3

16 Culpeper, J. (2009). Impoliteness: Using and Understanding the Language of Offence. ESRC project website: http://www.lancs. ac.uk/fass/projects/impoliteness https://doi. org/10.1017/CBO9780511975752

17 Culpeper, J. (2013). Impoliteness: questions and answers. In Jamet, D. \& Jobert, M. (Eds.), Aspects of Linguistic Impoliteness (pp. 2-15). Newcastle upon Tyne: Cambridge Scholars Publishing.

18 Culpeper, J. (2021). Sociopragmatics: Roots and Definition. In Haugh, M., Kádár, D., \& Terkourafi, M. (Eds.), The Cambridge Handbook of Sociopragmatics (Cambridge Handbooks in Language and Linguistics, pp. 15-29). Cambridge: Cambridge University Press. doi: 10.1017/9781108954105.003. https://doi.org/10.1017/9781108954105.003

19 Culpeper, J. \& Tantucci, V. (2021) The principle of (im)politeness reciprocity. In Journal of Pragmatics, 175, 146-164, https://doi. org/10.1016/j.pragma.2021.01.008
20 Curtin, M. (1985). A question of manners: Status and gender in etiquette and courtesy. The Journal of Modern History, 57(3), 395-423. Retrieved from: https:// www.jstor.org/stable/1879686 https://doi. org/10.1086/242859

21 Davidson, J. (2004). Hypocrisy and the Politics of Politeness. Manners and Morals from Locke to Austen. Cambridge: Cambridge University Press. Retrieved from: https://books.google.co.za/ books?id=uKvR8Yh_mgOC https://doi. org/10.1017/CBO9780511484179

22 de Mourgues, O. (2010). Two French Moralists: La Rochefoucauld and La Bruyère. Cambridge: Cambridge University Press.

23 de Oliveira, R. (2013). Manifestations émotionnelles de la dislocation: le cas de l'agacement. In Baider, F., \& Cislaru, G. (Eds). Cartographie des émotions. Paris: Presses de la Sorbonne (pp. 211-224). http://books. openedition.org/psn/2497

24 de Oliveira, R. (2015). Du rapport entre la négation et l'impolitesse dans les échanges d'informations face à face en français. AlfaRevista de Linguística, 29. doi: http://dx.doi. org/10.1590/1981-5794-1509-5

25 The Earliest Books Written of Etiquette and Table Manners ... in Medieval Times, the Renaissance and Beyond. (2014, March 13) Etiquipedia. Retrieved from: http://etiquipedia.blogspot.com/2014/03/the-earliest-books-written-of-etiquette.html

26 Ehlich, K. (1992). On the historicity of Politeness. In Watts, R. J., Ide, S. \& Ehlich, K. (Eds.), Politeness in Language: Studies in its History and Practice, vol. Trends in Linguistics, Studies and Monographs (pp. 71-107). Berlin: Mouton de Gruyter.

27 Elias, N. (1982). The Civilizing Process, Vol. 1: The History of Manners. Translated from the German by Edmund Jephcott. New York: Pantheon Books, 1982.

28 Erasmus, D. (1530). De civilitate morum puerilium ("On civility in children"). Retrieved from: https://books.google.co.za/ books?id=QFv88TLth78C

29 Fraser, B. (1998). Threatening revisited. Forensic Linguistics, 5(2), 159-173. 10.1558/ sll.1998.5.2.159

30 Galatanu, O., Bellachhab, A., \& Cozma, 
A. (Eds.) (2014). Actes rassurants, actes menaçants : sémantique et pragmatique de l'interaction verbal. SCOLIA 28/2014.

31 Goffman, E. (1967). On face-work. An analysis of ritual elements in social interaction. In Ders: Interaction Ritual, 5-45. New York: Doubleday. https://doi. org/10.4324/9780203788387-2

32 Grice, P. ([1975] 1979). Logique et Conversation. Communications, 30, 57-62. https:// doi.org/10.3406/comm.1979.1446

33 Hitchings, H. (2013). For the holidays, a brief history of manners. Los Angeles Times, November 28, 2013. Retrieved from: https:// www.latimes.com/opinion/op-ed/la-oehitchings-manners-20131128-story.html

34 Kasper, G. (1990). Linguistic politeness: Current research issues. In University of Hawai'i Working Papers in ESL, 9(1), 1-33.

35 Kerbrat-Orecchioni, C. (2010). L'impolitesse en interaction: Aperçus théoriques et étude de cas, Lexis: Journal in English Lexicology, HS2, 2010, 35-60. doi: https://doi. org/10.4000/lexis.796.

36 Kerbrat-Orecchioni, C. (2013). Politeness, non-politeness, "polirudeness". The case of political TV debates. In Jamet, D., \& Jobert, M. (Eds.), Aspects of linguistic impoliteness (pp. 16-45). Newcastle upon Tyne: Cambridge Scholars Publishing.

37 La Bruyère, J. de (1688) Les Caractères [Characters]. Retrieved from: https:// short-edition.com/fr/classique/jean-de-labruyere/de-la-societe-et-de-la-conversation

38 Lakoff, R. (1973). The logic of politeness or minding your P's and Q's. Proceedings from the Annual Meeting of the Chicago Linguistic Society, 9(1), 292-305.

39 Lakoff, R. T. (1977). What you can do with words: Politeness, pragmatics, and performatives. In Rogers, A., Wall, B., \& Murphy, J. P. (Eds), Proceedings of the Texas Conference on Performatives, Presupposition, and Implicatures (pp. 79-105). Arlington: Center for Applied Linguistics.

40 Leech, G. (1983). Principles of Pragmatics. London: Longman

41 Lestz, M. (2014, February 26). It Pays to be Polite in France [blog post]. Retrieved from: https://curiousrambler.com/2014/02/26/itpays-to-be-polite-in-france/
42 Locher, M. A. (2008). Relational work, politeness and identity construction. In Antos, G., Ventola, E. \& Weber, T. (Eds.), Handbooks of Applied Linguistics. Volume 2: Interpersonal Communication (pp. 509-540). Berlin \& New York: Mouton de Gruyter.

43 Locher, M. A. and Watts, R. J. (2008). Relational work and impoliteness: Negotiating norms of linguistic behaviour. In Bousfield, D. \& Locher, M. A. (Eds.), Impoliteness in Language. Studies on its interplay with Power in Theory and Practice (pp. 77-99). Berlin \& New York: Mouton de Gruyter.

44 Meier, A. J. (1995). Defining politeness: universality in appropriateness. Language Sciences, 17(4), 345-356. https://www.sciencedirect. com/science/article/pii/0388000195000194 https://doi.org/10.1016/0388-0001(95)00019-4

45 Mejri, S. (2017). Les formules de politesse et de présentation. Paris: Garnier.

46 Mills, S. (2015). Language, culture and politeness. In Sharifian, R. (Ed.), The Routledge Handbook of Language and Culture (pp. 129-140). Abingdon, UK: Routledge. https:// doi.org/10.4324/9781315793993-17

47 Moïse, C. (2019) Espace public et fonction de l'insulte dans la violence verbale. In Lagorgette, D. (Ed.) Les insultes en français: de la recherche fondamentale à ses applications (pp. 201-219). Chambéry: Université de Savoie

48 O'Driscoll, J. (2007a). Brown and Levinson's face: How it can - and can't - help us to understand interaction across cultures. Intercultural Pragmatics, 4(4), 463-492. https:// doi.org/10.1515/IP.2007.024

49 O'Driscoll, J. (2007b). What's in an FTA? Reflections on a chance meeting with Claudine. Journal of Politeness. Research Language Behaviour Culture, 3(2), 243-268. https://doi. org/10.1515/PR.2007.011

50 Picard, D. (2014). Les rituels de politesse.In Picard, D. (Ed.), Politesse, savoir-vivre et relations sociales (pp. 48-70). Paris : Presses Universitaires de France. Retrieved from : https:// www.cairn.info/politesse-savoir-vivre-et-relations-sociales--9782130630838-page-48.htm https://doi.org/10.3917/puf.picar.2014.01

51 Preisler, B., \& Haberland, H. (1994). Review of M. Sifianou, Politeness phenomena in England and Greece: A cross-cultural perspective. Journal of Pragmatics, 22(2), 227-232. https://doi.org/10.1016/0378-2166(94)90073-6 
52 Scott, J. (1998). New Respectability for Manners Scholars Tackle a Topic Long Thought Too Trivial for All but Fussbudgets. New York Times, February 28, 1998. Retrieved from: https://www.nytimes.com/1998/02/28/ arts/new-respectability-for-manners-scholars-tackle-topic-long-thought-too-trivial.html

53 Sifianou, M. (2010). Review of Locher, M. A., \& Bousfield, D. (Eds.) (2008) Impoliteness in Language: Studies on its Interplay with Power in Theory and Practice. Berlin \& New York: Mouton de Gruyter. In Language in Society, 39, 119-122. https://doi.org/10.1017/ S0047404509990674

54 Terkourafi, M. (2015). Review of The pragmatics of politeness by Geoffrey Leech. In Language 91(4), 957-960. https://doi.org/10.1353/ lan.2015.0061
55 Van Laun, H. (1885). Introduction. In The "Characters" of Jean de La Bruyère. London: John C. Nimmo. Retrieved from: https:// gutenberg.org/ebooks/46633.

56 Watts, R. J. (1991). Power in Family Discourse. Berlin: Mouton de Gruyter. https://doi. org/10.1515/9783110854787

57 Watts, R. J. (2003). Politeness. Cambridge: Cambridge University Press. https://doi. org/10.1017/CBO9780511615184

58 Wierzbicka, A. (1999). Emotions Across Languages and cultures: Diversity and Universals. Cambridge: Cambridge University Press/Paris: Editions de la Maison des Sciences de l'Homme.https://doi.org/10.1017/ CBO9780511521256

\section{Santrauka}

\section{Ruth de Oliveira. Apie bendradarbiavimą ir (ne)mandagumą bendraujant prancūzų kalba}

Išsamiame Culpeper'io (2009) tyrime apie tai, kaip vartojami su nemandagumu susiję terminai, ypač atsižvelgiant i žmonių lūkesčius viešujų paslaugų kontekste, terminas „prancūzas“ atsiranda du kartus, kartu su žodžiu „,durininkas“, „apsaugininkas“, „barmenas“, „padavèja“, „padavèjas“, „, ,iujorkietis“, „personalas“. Ar remiantis tuo galima daryti prielaidą, kad kasdieniame bendravime prancūzų kalba susikerta bendradarbiavimo principai (Grice, 1975) ir mandagumas, todèl kalbètojai apibūdinami kaip nemandagūs? Jei taip yra, kodèl? Kaip tai vyksta? Ar šis apibūdinimas būdingas viešujų paslaugų kontekstui, ar jis apima ir kitas socialinio gyvenimo sritis? Siekiant pateikti atsakymus į šiuos klausimus, šis tyrimas remiasi pokalbių analizès sistema, taikant sociopragmatinị metodą (nuo Austin, 1962, iki Kerbrat-Orecchioni, 2010, ir Culpeper, 2021). Remdamasis sociokultūriniais ir istoriniais veiksniais (Bourdieu, 1984; La Bruyère, 1688), Culpeper'is nagrinèja kalbinio (ne)mandagumo sampratą (Culpeper, 2009, 2021; Curtin, 1995; Meier, 1995) sąveikoje su Grice'o (1975) bendradarbiavimo principais. Šiuo tikslu mes nagrinejjame pasisveikinimo ritualą, ypač apsikeitimą „bonjour“ kasdienèje socialinèje sąveikoje prancūzakalbiame kontekste, naudodami autentišką duomenų rinkini (Reddit, 2014). Mūsų analizès rezultatai rodo, kad tam tikrose situacijose, kai šio ritualo simetrija pažeidžiama ir aktas nepavyksta, prancūzakalbiai mandagumui priskiria aukštesni ịvertinimą nei bendradarbiavimui, sukeldami priešingą reiškinị - nemandagumą.

About the Author

\section{RUTH DE OLIVEIRA}

French Department, University of Cape Town, South Africa

\section{Research interests}

Discourse analysis, social interactions, relations between syntax, semantics, and pragmatics

\section{Address}

$2^{\text {nd }}$ Floor, Room 205, Beattie Building, University Avenue, Upper Campus, University of Cape Town, Rondebosch - 7700, Cape Town, South Africa

E-mail ruth.deoliveira@uct.ac.za

ORCID iD https://orcid.org/0000-0003-0100-0259 